\title{
Facing The New Normal Literacy: Information Technology Skill And Information Quality Strategy
}

\author{
Echan Adam', Muhammad Iqbal Fasa ${ }^{2}$, Roymon Pandjaitan ${ }^{3}$, Astil Harli Roslan ${ }^{4}$, \\ Resista Vikaliana ${ }^{5}$ \\ \{echanadam@ung.ac.id ${ }^{1}$, miqbalfasa@radenintan.ac.id ${ }^{2}$,roymon_panjaitan@yahoo.com ${ }^{3}$ \}
}

Universitas Negeri Gorontalo, Indonesia ${ }^{1}$, Universitas Islam Negeri Raden Intan Lampung, Indonesia ${ }^{2}$, Universitas Sains dan Teknologi Komputer Semarang, Indonesia ${ }^{3}$, Universitas Muhammadiyah Kendari, Indonesia ${ }^{4}$ Institut Ilmu Sosial dan Manajemen STIAMI, Indonesia ${ }^{5}$

\begin{abstract}
This research focus to analyze the relationship between information technology skills (ITS) and information quality strategies (IQS) to increase the performance of individual performance (IP). Sampling Several 259 respondents across generations and across education. Data collection techniques for questionnaires and interviews. The SEMPLS Compound Path Test is used in this study to contribute data from the analysis of pathways mediated by the user's interest and the moderation of learning styles to the enhancement of individual learning methods. Results have shown that ITS and IQS has contributed to IP, while the interest of the user as mediator has not been able to mediate significantly on IP and learning style (LS) of one has not been able to moderate IP improvement. The results suggest that every individual with not only good knowledge in science but also an interest in using the latest ITS and an efficient IQS is expected to change the learning literacy method quickly and effectively.
\end{abstract}

Keywords: Information quality strategy, Information technology skill, User interests, Individual performance, Learning style.

\section{Introduction}

The report is defined as the implication of the document with the perspective of knowledge function [38] and provides the necessary skills for the future role of an individual as a decision-maker [61]. A large number of methods of information and their benefits can be obtained from the system depending on its use [52] In addition to the quality of the news built, information technology skills [18] have built many encouraging models, each with a set that is not similar gain determinant. Research filed [17], [35] suggests that the urge for technological information is not an expense in technology, but the use of authentic technology. Another thing that is said to have mutual factor compulsory choice of complications and disruptions type of information technology obsession [4], [56]. Therefore, to know the interest of users requires the quality of reports and the capabilities of information technology on each single.

Some of the other obstacles needed to improve individual performance are the need for quality information and individual visibility capabilities. Some early researchers such as [47], [16], [63] suggest that the quality of information and the system determines conceptual and empirical effectiveness in individual performance outcomes. The same thing from the 
relationship of information technology skills on individual performance with the ability of technology skills one can improve the actual performance in the industry [25], in addition [31] arguing technology skills is an implementation of a form of success in the empowerment of individual workforce. [36] It also associates the use of information system skills to significantly impact the individual functional performance in terms of productivity, efficiency, effectiveness and cost. But from past researchers ' discussions have never filled a vacancy in the quality of information and information technology skills mediated by users ' interests. Thus user interest contributions in this study can be a measure of individual performance optimization.

From the study results according to [3], [1], [46], User interests are also influenced by the quality of information through the Web can affect individual performance as a user. But information from Internet Information technology fundamentally affects how information is misdispersed so that it is recorded on the information that individuals receive [37]. From that gap or inconsistency, this study assumes that the user's interest in information grows, we moderate the interest of the user with the learning style to know if it can strengthen in improving individual performance.

Programming language learning methods, supported with online forums [55], [43] and productive engagement of employees can enhance learning academic performances by achievement [15]. Another thing, the visual learning style channels will provide cognitive skills [14], [39] that users use in a digital atmosphere, but digital learning difficulties in addition to involving objectivity the ability to adapt the software or to activate numerical procedures such as coherent, motor, sociological, and obsessive users are also important to develop their personal talents [19], [34], [57]. Thus the awareness style of channel utilization of information and skill changes can be used as a reference to contribute to the elaboration of certain potential. The aim of the study contributes to the conceptual analysis of the user's interest in a more effective learning style with information systems technology literacy and skill utilization in order to improve the competitive individual's performance.

\section{Literature Review}

\subsection{Quality Information}

Data quality shows the consistency of the data system performance, which may be a document or electronic display [27] Once, the model of this information quality success developed by DeLone and McLean [49], QI can be defined as suitability for the use of information [44]. In conducting online learning, students certainly need information that is in the process, by which, the quality of information is important because the information can not be used if it is not trustworthy. Therefore, it is very important [45], the dimensions of the quality of information are not detached from the needs of each party, and in general, only part of the relevant dimensions are used by needs. The unique challenges encountered and wants of the clients decide what quality attributes are important and which quality levels are needed in any dimension [8]. In the variable quality of the information using dimensions consisting of accuracy, timeliness, understanding, and fragility [54]. The quality of the informed gives a significant impact on the user's interest [58]. 


\subsection{Information Technology Skills}

Information technology skills are managerial, intrapersonal, and interpersonal skills used to solve information technology-related work issues [60], it also describes students who have technical skills related to technology have more value than having only academic skills in general. Despite the increasingly important soft skills, very little systematic research conceptualized the skills related to information technology and even less measuring these skills [5]. In the variable of information technology skills using a dimension consisting of willingness to learn, passionate, logical ability, and ability to solve problems [6]. Utilization of information technology can improve performance [23].

\subsection{User interests}

Intelligent interest is an endeavor you enjoy and the topics that you'd like to know about [65] The topic you want to ask, learn, gain knowledge or include by the representatives is further defined as the user preferences (agents may be an individual user, a community of users or other smart operatives). User interest can be regarded as the background of knowledge from the user, hence it can be regarded as a context for the literature on Web [13]. This is in line with research done by [50] stating that user interest is one of the important factors to influence the decision making process of the user, which has been demonstrated by the study of psychology and sociology. [62] The emergence of interest in using the system is influenced by the presence of performance, business expectations, social influences and conditions that facilitate an individual.

\subsection{Learning Style}

LS is part of the greater perceptions of the students. [41], the LS of each student differs, should not the faculty of University assume that the student learning style is the same, and will be a commitment of the university education professors to widen ones report of learning activities expand the field of LS as many adult students as possible to achieve more effective learning [12]. In his study [30], He clarified that most researchers promoted the use of knowledge in teaching styles to improve their learning skills by using different teaching exercises and to help their students become cleverer by using less convenient styles. In the LS variables using dimensions consisting of visual, auditory and kinaesthetic [20] Learning styles are key to developing performance in work as well as in schools [40].

\subsection{Individual performance}

In organizational therapy and organization, individual success is the central principle. Scientists have developed strides in reiterating and extending the success definition over the last 10 or 15 years [9] with the changes we are currently watching in the current organization, the concept of performance and performance requirements is changing as well [33] Human output over time is unpredictable. The variation in the success period of a company tells (1) The learning process and other long-term changes and (2) temporary changes in performance [59]. The previous research shows that providing the same learning materials and providing the same teaching conditions for all students can lead to a decline in learning performance without considering different background characteristics, prior knowledge, experience, and learning talent [21]. Individuals can use technology to assist them in carrying out their duties [26]. QI has a significant relationship to IP [2]. 


\section{Method}

Partial Least Squre (PLS) is used as a data analysis technique in this research PLS is an alternative approach that shifts from covariance-based SEM to variant-based approaches [51]. This study utilized the structural equation modeling technique to analyze the relationship between the quality of information, information skills and technology as well.

A questionnaire was prepared and sent out to Indonesia college students who receive online learning. The questionnaire distributed online almost throughout Indonesia in JuneJuly 2020, nevertheless, only 259 respondents returned. This research used the method of modeling structural equations to evaluate the ties around:

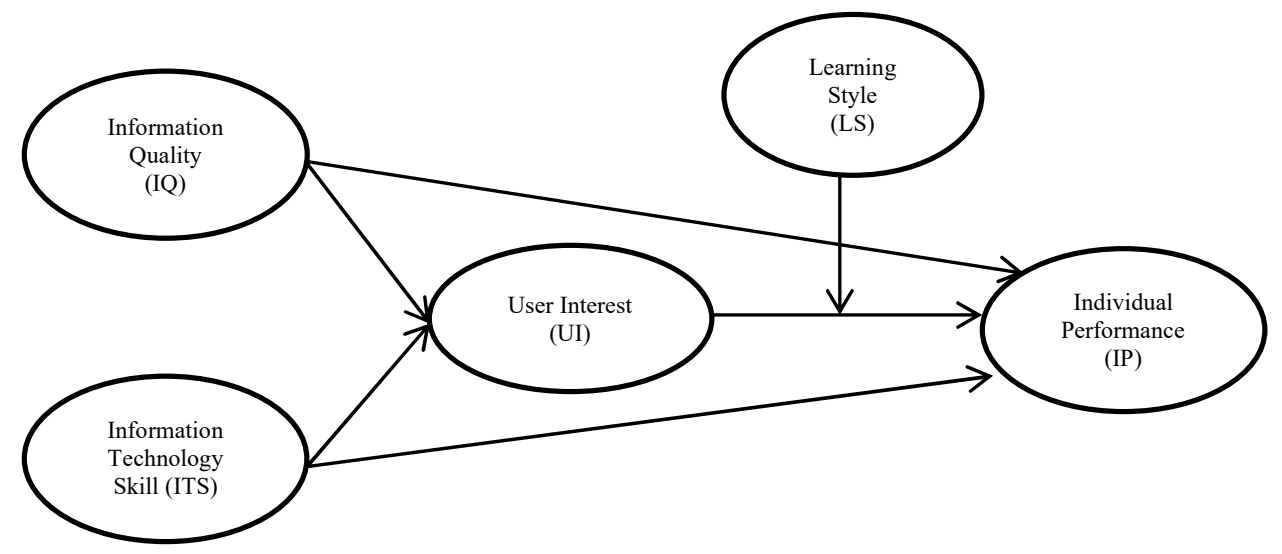

Fig.1. The Conceptual Research Model

In most studies of social and behavioral sciences, researchers often encounter theoretical construct (s) that cannot be observed directly [51].

a) Latent variables are variables that cannot be measured directly but can only be measured with one or more manifest variables. This variable is also called an unobserved variable. In this study, each endogenous and exogenous variables are latent variables, namely Information Quality, Information Technology Skills, User Interest, Individual Performance, Learning Style.

b) Exogenous variables, often also known as independent variables, are variables that are not influenced by other variables and affect the dependent variable. In SEM, this variable is indicated by the arrows coming from this variable towards the endogenous variable. In this research, including this variable are Information Quality, Information Technology Skills.

c) Endogenous Variables Endogenous variables or often also known as dependent variables, are variables that are influenced by independent (exogenous) variables. In SEM, this variable is indicated by the arrows going to this variable. In this research, including this variable are User Interest, Learning Style, Individual Performance. 
Table 1. The Research Variables and Indicators

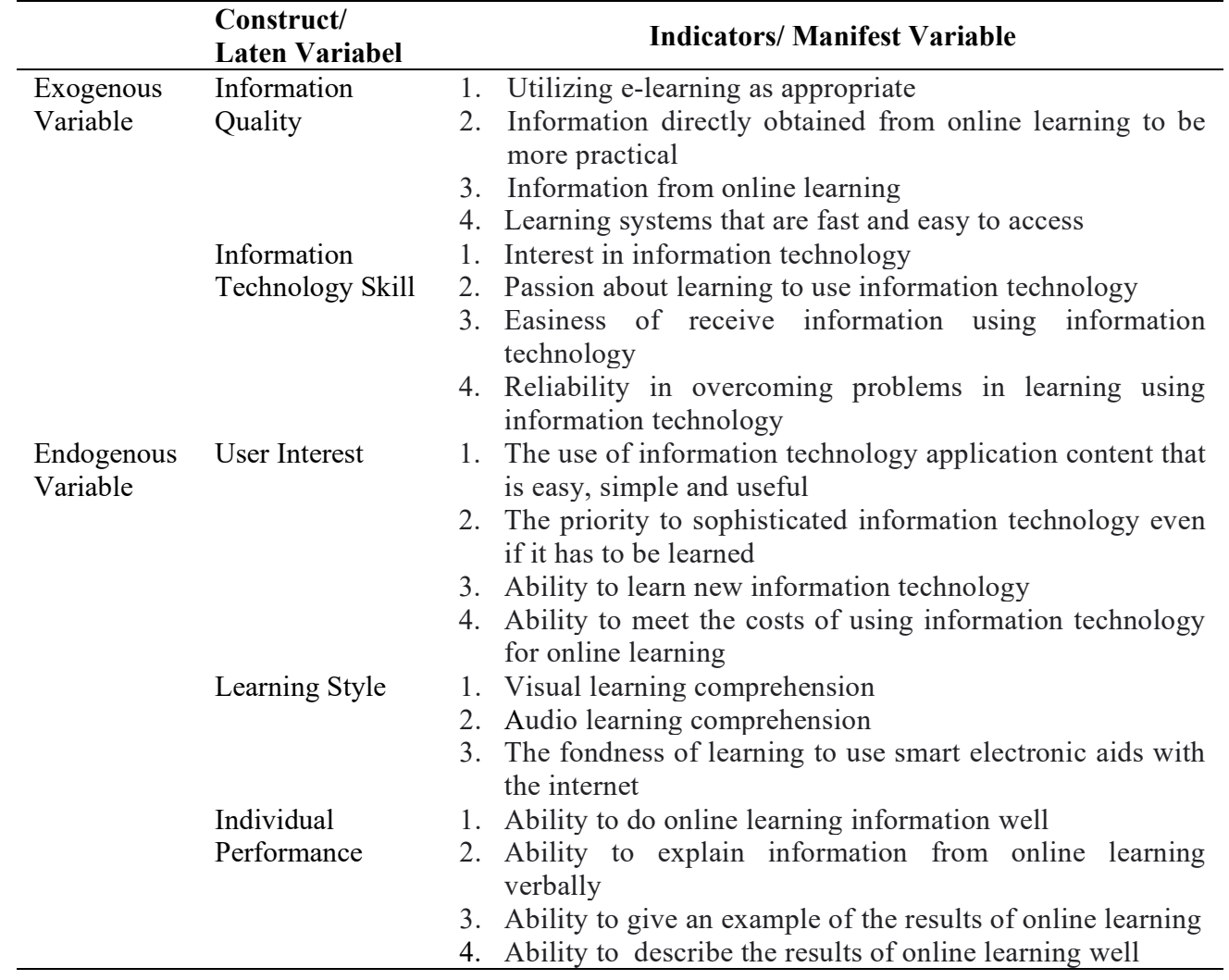

Based on [29], the postulate expended remains like charts.

1. The numerical hypothesis for the inner typical is:

$\mathrm{H} 0: \gamma \mathrm{i}=0$

H1 : $\gamma \mathrm{i} \neq 0$

2. The arithmetical hypothesis for outer exemplary is:

$\mathrm{H} 0: \lambda \mathrm{i}=0$

$\mathrm{H} 1: \lambda \mathrm{i} \neq 0$

Hypothesis 1 (H1):

There is an express or indirect influence among IQ and IP.

Hypothesis 2 (H2):

There is a through or indirect influence concerning ITS and IP 
Hypothesis 3 (H3):

There is a straight or indirect influence amongst IQ and IP through UI

Hypothesis 4 (H4):

There is an uninterrupted or indirect influence amid ITS and IP through UI

Hypothesis 5 (H5):

There is an express or indirect influence among IQ and UI

Hypothesis 6 (H6):

There is an express or indirect influence among ITS and UI

Hypothesis 7 (H7):

There is a direct or indirect influence amongst UI what is more IP which is moderated by LS

\section{Result And Discussion}

\subsection{Measurement Model Assessment (Outer Model)}

In SEM-PLS, the evaluation of the first outer model is done to determine the validity and reliability of indicators that measure latent variables [53], [28]. The validity and reliability testing of indicators refer to measurements of convergent validity, linear validity, and composite reliability.

\begin{tabular}{|c|c|c|c|c|c|}
\hline Construct & Items & Loadings & AVE & CR & $\begin{array}{l}\text { Cronbach's } \\
\text { Alpha }\end{array}$ \\
\hline $\begin{array}{l}\text { Information Quality } \\
\text { (IQ) }\end{array}$ & $\begin{array}{l}\text { IQ1 } \\
\text { IQ2 } \\
\text { IQ3 } \\
\text { IQ4 }\end{array}$ & $\begin{array}{l}0.811 \\
0.837 \\
0.841 \\
0.796\end{array}$ & 0.675 & 0.892 & 0.839 \\
\hline $\begin{array}{l}\text { Information } \quad \text { Technology } \\
\text { Skill } \\
\text { (ITS) }\end{array}$ & $\begin{array}{l}\text { ITS1 } \\
\text { ITS2 } \\
\text { ITS3 } \\
\text { ITS4 }\end{array}$ & $\begin{array}{l}0.771 \\
0.853 \\
0.786 \\
0.766\end{array}$ & 0.632 & 0.873 & 0.805 \\
\hline $\begin{array}{l}\text { User Interest } \\
\text { (UI) }\end{array}$ & $\begin{array}{l}\text { UI1 } \\
\text { UI2 } \\
\text { UI3 } \\
\text { UI4 }\end{array}$ & $\begin{array}{l}0.812 \\
0.835 \\
0.829 \\
0.675\end{array}$ & 0.625 & 0.869 & 0.797 \\
\hline $\begin{array}{l}\text { Learning Style } \\
\text { (LS) }\end{array}$ & $\begin{array}{l}\text { LS1 } \\
\text { LS2 } \\
\text { LS3 }\end{array}$ & $\begin{array}{l}0.778 \\
0.659 \\
0.804\end{array}$ & 0.562 & 0.793 & 0.618 \\
\hline $\begin{array}{l}\text { Invidual Performance } \\
\text { (IP) }\end{array}$ & $\begin{array}{l}\text { IP1 } \\
\text { IP2 } \\
\text { IP3 } \\
\text { IP4 }\end{array}$ & $\begin{array}{l}0.873 \\
0.778 \\
0.883 \\
0.800\end{array}$ & 0.697 & 0.902 & 0.855 \\
\hline $\begin{array}{l}\text { AVE }=\text { Average Vari } \\
\text { composite reliability } \\
\text { Source: Data processed, } \\
2020\end{array}$ & nce & tracted; & $=$ & & \\
\hline
\end{tabular}




\subsection{Convergent Validity}

Convergence validity testing shall be measured loading the importance of each index of its variables. Charges above 0.700 are highly recommended, but for exploratory research, loads of 0.400-0.699 are acceptable [32], [64]. The Loading Factor of the Highest Rated Indicator is the strongest or most important indicator to reflect on the latent variables concerned. The value of the loading factor interpreted the contribution of each indicator to its variable variables. Table 2 shows the value of the loading indicators - latent variable indicators, i.e., more than $0.600-0.700$. These results can be concluded that the research variables have been capable of being formed or well explained by their respective indicators and can be considered a valid convergence of indicators.

\subsection{Discriminant Validity}

Intended to test whether the research variable indicator is valid for explaining or reflecting latent variables formed from other latent variables. The discriminant validity of the measurement model was assessed on the basis of the extracted (AVE) average variance for the latent variable score component. The AVE value should be more than 0,500 [22], [7]. The AVE value above 0.500 indicates that the linear validity has been reached, i.e. the indicator used has been able to explain the variables formed by other variables. Table 2 shows that the AVE value of each latent variable is greater than the value of 0.500 . This means that the measurement model has been achieved and that discrimination is valid.

\subsection{Composite Reliability and Cronbach's Alpha}

Composite reliability and Cronbach alpha are used to test the consistency of the indicators of the latent variables that form them. The value of composite reliability is said to be good if it is above 0.700, while the minimum value of 0.600 is acceptable for Cronbach's alpha [7], [22], [48]. Table 2 shows the alpha coefficient of Cronbach from 0.618 to 0.855 . The value is more than 0.700 , and the acceptable value limit is 0.600 . The lowest Composite reliability is 0.792 , and the highest value of 0.902 shows that the indicators used are consistent and adequate to inform the latent variables. The indicators used in the study met the criteria for use in the measurement of their variables because they are valid and have high reliability and consistency. From the assessment of convergent validity and linear validity, as well as the reliability of the composite and Cronbach alpha, it can be concluded that the indicators are a latent variable gauge, each of which is an accurate and reliable gauge.

\subsection{Structural Model Testing (Inner Model)}

a) Goodness of Fit

The relationship between the constructs, $p$-values and the determinant coefficients of the research model is to be seen in the assessment of the inner model [24]. Structural models for $\mathrm{R}$-square $\left(\mathrm{R}^{2}\right)$ and $\mathrm{Q}^{2}$ (predictive relevance models) were evaluated in this study. $\mathrm{Q}^{2}$ shows the level of the model results as well as the estimated parameters that are assessed on the basis of the observations made. $Q^{2}$ is calculated on the basis of the total value of $R^{2}$. The magnitude of $\mathrm{Q}^{2}$ approaching the value of 1 indicates the model has a predictive value of relevance, which means that the model is improving [10]. Following the results of the $\mathrm{R}^{2}$ and $\mathrm{Q}^{2}$ calculations, the research model is shown: 
Table 3. The value of Goodness of fit

\begin{tabular}{llll}
\hline Exogenous Variable & Endogenous Variable & $\mathbf{R}^{\mathbf{2}}$ & $\mathbf{Q}^{\mathbf{2}}$ \\
\hline IQ, ITS & UI & 0.470 & \multirow{2}{*}{0.714} \\
IQ, ITS, UI*LS & IP & 0.460 & \\
\multicolumn{2}{l}{ Source: Data processed, 2020 } & & \\
\hline
\end{tabular}

Value of the coefficient of determination $\left(\mathrm{R}^{2}\right)$ derived from the Quality Information Model and IT skills to the User Interests of 0470. This means that the variable model of user interests can be explained by $47 \%$ of quality information and IT skills. In the same way, the variable performance variable model can be explained by variable quality information, IT skills, user interests, and user interests with a $46 \%$ moderation learning style. The rest is influenced by other variables outside the study. The value of $\mathrm{Q}^{2}$ indicates that the predictive value is relevant 0.714. These results may mean that the accuracy or accuracy of the model of this research can explain the variable diversity of quality information, IT skills, and variable moderation learning style to 71.4 percent of user interests and individual performance. Thus, the model has a good estimation value.

\section{b) Hypothesis Testing}

The hypothesis evaluated by comparing the value of the framework path parameter coefficient. Hypothesis testing of the model is performed on the basis that the relationship model built in the study is appropriate (Goodness of fit). The objective of testing structural relationship models is to determine the correlation between variables or latent constructs. From the output of the SEM-PLS, the test of structural models and hypotheses is performed by looking at the estimated value of the path coefficient, and the $t$-statistical value and the value of the significance.

Table 4. Structural Model Hypothesis Testing for Direct and Indirect Effect

\begin{tabular}{lllllll}
\hline Hypothesis & Relationship & \multirow{2}{*}{ Coefficient } & $\begin{array}{l}\text { Std. } \\
\text { Error }\end{array}$ & t-values & p-values & Decision \\
\hline H1 & (IQ $\rightarrow$ IP) & 0.254 & 0.120 & $2.113^{*}$ & 0.036 & Suported \\
H2 & (ITS $\rightarrow$ IP) & 0.149 & 0.130 & 1.152 & 0.251 & Not Suported \\
H3 & (IQ $\rightarrow$ UI $\rightarrow$ IP) & 0.029 & 0.088 & 0.323 & 0.373 & Not Suported \\
H4 & (ITS $\rightarrow$ UI $\rightarrow$ IP) & 0.067 & 0.186 & 0.359 & 0.360 & Not Suported \\
H5 & (IQ $\rightarrow$ UI) & 0.230 & 0.111 & $2.067 *$ & 0.040 & Suported \\
H6 & (ITS $\rightarrow$ UI) & 0.535 & 0.091 & $5.892 * *$ & 0.000 & Suported \\
H7 & (UI*LS $\rightarrow$ IP) & 0.190 & 0.625 & 0.304 & 0.381 & Not Suported \\
\hline$* *$
\end{tabular}

**sig. $1 \% ;{ }^{*}$ sig. $5 \%$

Source: Data processed, 2020

Based on the conceptual model, the test of the relationship models and hypotheses between variables is carried out by testing the pathway coefficient of direct influence and indirect influence (mediation and moderation). Of the four direct influences between the variables tested, there are three significant direct influences and one insignificant direct influence. Meanwhile, indirect influence models (both mediation and moderation influences) between variables show insignificant results.

The coefficient of direct influence of quality information on individual performance $(\mathrm{H} 1)$ is positive and significant for alpha 5 percent, while IT skills on individual performance (H2) have no significant impact. Quality information and IT skills against user interests (H3; H4) Each has a significant positive impact on the Alpha 5\% and 1\%. Significant influence shows 
that the built-up hypothesis is acceptable, while others are rejected.The results of this study explain the quality of the information received and IT skills owned can increase individual interest in the use of information technology in the online learning process and use to improve the individual performance of students in Indonesia. The results of this research can provide relevant information to its primary stakeholders for university lecturers about the online learning outcomes. Further research results outlined as follows.

The study found that information quality has a significant positive influence on users ' interests. This research proves that the higher the quality of information that students receive in online learning according to timeliness, accuracy, understanding, and the rigour of information. So it can increase student interest in utilizing online learning. That is, lecturers are required to maintain the quality of information and services to be able to encourage students to use information technology and follow online learning. This research is in line with the findings of [58]. The quality of the information in the form of quality audiovisual content can attract users to use it.

At the same time, this study revealed that the quality of information has a direct influence on individual student performance in Indonesia. Simply put, the better the information received by students, the more students are motivated to increase their achievement independently, moreover, when their prayers recognize the students' efforts and outcomes. [2] Also reveal flexible, easy-to-access online learning, providing up-to-date, accurate and interactive and responsive information, increasing student interest in online learning.

Associated IT skills influence the user's interest shows significant positive impact directly on the user's attention but has no effect on individual performance. The results revealed that IT skills affected users' interest in the utilization of information technology, proving that more and more students are motivated to utilize online learning and strive to follow it. The results of this study are consistent with the findings of [58] which reveals that the quality of experience that someone has against IT will affect the user to choose Online Services. In this case, students with IT skills can inspire their interest in utilizing information technology in online learning. However, with IT skills, students have not automatically increased their achievements as well. It undoubtedly depends on the individual's ability and the learning process of students in capturing and analyzing the information received. This results by the findings of [11], [42] which reveals that use of IT does not impact performance. Student learning styles are not yet able to moderate the influence of user interest on individual performance. Studying students independently through online learning has not entirely influenced the performance, except with the help and guidance of lecturers.

Overall it can be concluded that quality strategy and IT skills become the primary key that students have to have. The positive effect can be felt directly by the students by utilizing the maximum information technology as well as supporting the individual performance improvement of students in the new normal era. Lecturers and leadership policy support should prioritize quality content and services to improve student literacy when applying online learning at universities in Indonesia.

\section{Conclusions}

This study examines the relationship between information quality strategy, informational technology skills mediated by user interest and there are learning styles that functioned to moderate performance in individual, especially for education literacy development. Previous 
empirical studies have examined the relationship of quality information and technological developments in developed countries. There is limited evidence to demonstrate that a study examining the effects of the moderation of learning styles on the individual interest relationship of technological information that has been conducted in the country is still developing. The study showed that the leadership of information quality and the ability to adapt individual technology skills is a crucial factor in the face of learning literacy methods in the current new normal era. The results of this study emphasized that the user's interest in information in terms of receiving quality information and technological skills development should be optimally followed for an increase in individual performance values. Learning style in education literacy is a method that must be developed in accordance with individual characteristics - each individual who can certainly support the learning process independently. It is very important to develop your own potential by implementing learning styles and interests using information technology in the new normal era to continue to evolve in technological literacy.

\section{References}

[1] T. Ahn, S. Ryu, and I. Han, "The impact of the online and offline features on the user acceptance of Internet shopping malls," in Electronic Commerce Research and Applications, 2004, doi: 10.1016/j.elerap.2004.05.001.

[2] A. H. Aldholay, O. Isaac, Z. Abdullah, and T. Ramayah, "The role of transformational leadership as a mediating variable in DeLone and McLean information system success model: The context of online learning usage in Yemen," Telemat. Informatics, vol. 35, no. 5, pp. 14211437, 2018, doi: 10.1016/j.tele.2018.03.012.

[3] B. M. Ali, and B. Younes, "The Impact of Information Systems on user Performance: An Exploratory Study,” J. Knowl. Manag. Econ. Inf. Technol., 2013.

[4] Y. K. Alotaibi and F. Federico, "The impact of health information technology on patient safety,” Saudi Medical Journal. 2017, doi: 10.15537/smj.2017.12.20631.

[5] S. Ang and S. A. Slaughter, "The Missing Context of Information Technology Personnel: A Review and Future Directions for Research," Fram. Domains IT Manag., pp. 305-327, 2000, [Online]. Available: http://www.pinnaflex.com/framing.

[6] I W. Arnata and S. Surjoseputro, "Evaluation of Soft Skills in New Student Learning at the Faculty of Agricultural Technology Udayana University," J. Educ. and Learning, vol. 21, no. 1, pp. 01-09, 2014.

[7] R. P. Bagozzi and Y. Yi, "On the evaluation of structural equation models," J. Acad. Mark. Sci., vol. 16, no. 1, pp. 74-94, 1988, doi: 10.1007/BF02723327.

[8] C. Bizer and R. Cyganiak, "Quality-driven information filtering using the WIQA policy framework," Web Semant., vol. 7, no. 1, pp. 1-10, Jan. 2009, doi: 10.1016/j.websem.2008.02.005.

[9] J. P. Campbell, "Modeling the performance prediction problem in industrial and organizational psychology," in Handbook of Industrial and Organizational Psychology, 1990.

[10] W. W. Chin, "The partial least squares approach to structural equation modelling. In Marcoulides G. A. (Ed.)," Mod. Methods Bus. Res., vol. 295, no. 2, pp. 295-336, 1998.

[11] K. W. Cho, S. K. Bae, J. H. Ryu, K. N. Kim, C. H. An, and Y. M. Chae, "Performance evaluation of public hospital information systems by the information system success model," Healthc. Inform. Res., vol. 21, no. 1, pp. 43-48, 2015, doi: 10.4258/hir.2015.21.1.43.

[12] F. Coffield, D. Moseley, E. Hall, and K. Ecclestone, "LSRC reference," Learning, p. 84, 2004, doi: 10.1016/S0022-5371(81)90483-7.

[13] Committee on Developments in the Science of Learning with additional material from the Committee on Learning Research and Educational Practice, How Experts Differ from Novices. 
National Academies Press, 2000

[14] A. M. R. Correia, "Digital Literacies for learning," Online Inf. Rev., 2007.

[15] F. Dağ and A. Geçer, "Relations between online learning and learning styles," Procedia - Soc. Behav. Sci., 2009, doi: 10.1016/j.sbspro.2009.01.155.

[16] W. H. DeLone and E. R. McLean, "Information systems success: The quest for the dependent variable," Inf. Syst. Res., 1992, doi: 10.1287/isre.3.1.60.

[17] S. Devaraj and R. Kohli, "Performance impacts of information technology: Is actual usage the missing link?," Manage. Sci., 2003, doi: 10.1287/mnsc.49.3.273.12736.

[18] M. El Ouirdi, A. El Ouirdi, J. Segers, and I. Pais, "Technology adoption in employee recruitment: The case of social media in Central and Eastern Europe," Comput. Human Behav., 2016.

[19] Y. Eshet-Alkali and Y. Amichai-Hamburger, "Experiments in digital literacy," Cyberpsychology Behav., 2004, doi: 10.1089/cpb.2004.7.421.

[20] N. Fleming, Teaching and learning styles: VARK strategies, 1st ed. Christchurch N.Z.: Neil Fleming, 2001.

[21] N. Ford, N. Ford, and S. Y. Chen, "Individual Differences, Hypermedia Navigation, and Learning: An Empirical Study,” J. Educ. Multimed. Hypermedia, vol. 9, no. 4, pp. 281-311, 2000 .

[22] C. Fornell and D. F. Larcker, "Evaluating Structural Equation Models with Unobservable Variables and Measurement Error," J. Mark. Res., vol. 18, no. 1, p. 39, 1981, doi: $10.2307 / 3151312$.

[23] Y. Ghorbanzad and M. Beig, "The impact of information technology on productivity using structural equations technique in Iran Behnoush Company," Manag. Sci. Lett., vol. 2, no. 4, pp. 1195-1202, 2012, doi: 10.5267/j.msl.2012.03.001.

[24] I. Ghozali, Structural Equation Modelling, Second Edition. Semarang : Universitas Diponegoro, 2008.

[25] T. F. Golob, "Structural equation modeling for travel behavior research," Transportation Research Part B: Methodological. 2003, doi: 10.1016/S0191-2615(01)00046-7.

[26] D. L. Goodhue and R. L. Thompson, "Task-technology fit and individual performance," MIS $Q$. Manag. Inf. Syst., vol. 19, no. 2, pp. 213-233, 1995, doi: 10.2307/249689.

[27] N. Gorla, T. M. Somers, and B. Wong, "Organizational impact of system quality, information quality, and service quality," J. Strateg. Inf. Syst., vol. 19, no. 3, pp. 207-228, 2010, doi: 10.1016/j.jsis.2010.05.001.

[28] J. F. Hair, Black, W. C., Babin, B. J., and Anderson, R. E. Multivariate Data Analysis (7th ed.). New York : Pearson, 2010.

[29] J. F. Hair, C. M. Ringle, and M. Sarstedt. PLS-SEM: Indeed A Silver Bullet. Journal of Marketing Theory and Practice, vol. 19, no. 2, pp.139-151, 2011, https://doi.org/10.2753/MTP1069-6679190202

[30] T. F. Hawk and A. J. Shah, "Using Learning Style Instruments to Enhance Student Learning," Decis. Sci. J. Innov. Educ., vol. 5, no. 1, pp. 1-19, Jan. 2007, doi: 10.1111/j.15404609.2007.00125.x.

[31] G. Houtzagers, "Empowerment, using skills and competence management," Particip. Empower. An Int. J., 1999, doi: 10.1108/14634449910271429.

[32] J. Hulland, "Use of partial least squares (PLS) in strategic management research: a review of four recent studies," Strateg. Manag. J., vol. 20, no. 2, pp. 195-204, Feb. 1999, doi: 10.1002/(SICI)1097-0266(199902)20:2<195::AID-SMJ13>3.0.CO;2-7.

[33] D. R. Ilgen and E. D. Pulakos, "Employee performance in today's organizations," in The Changing Nature of Performance: Implications for Staffing, Motivation, and Development., 1999.

[34] A. Karpati, "Digital literacy in education," Policy Br., 2011

[35] C. Kohli and L. Leuthesser, "Brand Equity: Capitalizing on Intellectual Capital," Ivey Bus. J., vol. 65 , no. 4, p. 74, 2001.

[36] I. A. Lee, "Relationship between the use of Information Technology (IT) and performances of 
Human Resources Management (HRM).," Diss. Abstr. Int. Sect. A Humanit. Soc. Sci., 2008.

[37] S. Lewandowsky, U. K. H. Ecker, C. M. Seifert, N. Schwarz, and J. Cook, "Misinformation and Its Correction: Continued Influence and Successful Debiasing," Psychol. Sci. Public Interes. Suppl., 2012, doi: 10.1177/1529100612451018.

[38] P. Lillrank, "The quality of information," Int. J. Qual. Reliab. Manag., 2003, doi: $10.1108 / 02656710310482131$.

[39] A. H. Littlejohn and L. A. J. Stefani, "Effective use of communication and information technology: bridging the skills gap," Res. Learn. Technol., 2011, doi: 10.3402/rlt.v7i2.11538.

[40] I. Maryani, L. Fatmawati, V. Y. Erviana, D. Kartika, M. Nur Wangid, and A. Mustadi, "Validity and reability of learning style scale of the elementary school students," Proceedings - Int. Conf. on Research in Educ., Sanata Dharma University, pp. 364-382, 2017.

[41] D. P. McAdams and J. L. Pals, "A new Big Five: Fundamental principles for an integrative science of personality," Am. Psychol., vol. 61, no. 3, pp. 204-217, 2006, doi: 10.1037/0003066X.61.3.204.

[42] R. Mcdermott, "Why Information Technology Inspired But Cannot Deliver Knowledge Management," Calif. Manage. Rev., vol. 41, no. 4, pp. 103-117, 1999.

[43] B. Means, Y. Toyama, R. Murphy, M. Bakia, and K. Jones, "Evaluation of Evidence-Based Practices in Online Learning," Structure, 2009.

[44] C. Min, W. Nan, L. Wei, and Y. Jingkun, "Preparation and properties of a carbon free precast block for ladle lining," Ind. Ceram., vol. 26, no. 3, pp. 209-212, 2006.

[45] V. Naicker and D. Jairam-Owthar, "The linkage of information quality to an executive decision support framework for the financial service sector of a developing economy," SA J. Inf. Manag., vol. 19, no. 1, Jun. 2017, doi: 10.4102/sajim.v19i1.781.

[46] S. Negash, T. Ryan, and M. Igbaria, "Quality and effectiveness in Web-based customer support systems," Inf. Manag., 2003, doi: 10.1016/S0378-7206(02)00101-5.

[47] R. R. Nelson and P. H. Cheney, "Training end users: An exploratory study," MIS Q. Manag. Inf. Syst., 1987, doi: 10.2307/248985.

[48] J. C. Nunnally, and Bernstein, I. H. Psychometric theory (3rd ed.). New York : McGrawHill, 1994.

[49] S. Petter, W. Delone, and E. R. McLean, "Information systems success: The quest for the independent variables," J. Manag. Inf. Syst., vol. 29, no. 4, pp. 7-62, Apr. 2013, doi: 10.2753/MIS0742-1222290401.

[50] X. Qian, H. Feng, G. Zhao, and T. Mei, "Personalized recommendation combining user interest and social circle," IEEE Trans. Knowl. Data Eng., vol. 26, no. 7, pp. 1763-1777, Jul. 2014, doi: 10.1109/TKDE.2013.168.

[51] T. Ramayah, J. Cheah, F. Cuah, H. Ting, and M. A. Memon, "Partial Least Squares Structural Equation Modeling (PLS-SEM) using SmartPLS 3.0". Pearson. 2018.

[52] K. A. Saeed and S. Abdinnour-Helm, "Examining the effects of information system characteristics and perceived usefulness on post adoption usage of information systems," Inf. Manag., 2008, doi: 10.1016/j.im.2008.06.002.

[53] R. E. Schumacker, and Lomax, R. G. A Beginner's Guide to Structural Equation Modeling. Psychology Press, 2004.

[54] P. Shamala, R. Ahmad, A. Zolait, and M. Sedek, "Integrating information quality dimensions into information security risk management (ISRM)," J. Inf. Secur. Appl., vol. 36, pp. 1-10, Oct. 2017, doi: 10.1016/j.jisa.2017.07.004.

[55] R. S. Shaw, "A study of the relationships among learning styles, participation types, and performance in programming language learning supported by online forums," Comput. Educ., 2012, doi: 10.1016/j.compedu.2011.08.013.

[56] L. Sigerson, A. Y. L. Li, M. W. L. Cheung, and C. Cheng, "Examining common information technology addictions and their relationships with non-technology-related addictions," Comput. Human Behav., 2017, doi: 10.1016/j.chb.2017.05.041.

[57] E. Soep, "The digital afterlife of youth-made media: Implications for media literacy education," Comunicar, 2012, doi: 10.3916/C38-2012-02-10. 
[58] J. Song, F. Yang, Y. Zhou, S. Wan, and H. R. Wu, "QoE Evaluation of Multimedia Services Based on Audiovisual Quality and User Interest," IEEE Trans. Multimed., vol. 18, no. 3, pp. 444-457, 2016, doi: 10.1109/TMM.2016.2520090.

[59] S. Sonnentag and M. Frese, "Performance Concepts and Performance Theory," in Psychological Management of Individual Performance, Chichester, UK: John Wiley \& Sons, Ltd, 2005, pp. 125.

[60] R. J. Sternberg and J. Hedlund, "Practical Intelligence, g, and Work Psychology," Hum. Perform., vol. 15, no. 1-2, pp. 143-160, Apr. 2002, doi: 10.1080/08959285.2002.9668088.

[61] J. R. Talburt, "Principles of Information Quality," in Entity Resolution and Information Quality, 2011.

[62] V. Venkatesh, M. G. Morris, G. B. Davis, and F. D. Davis, "User acceptance of information technology: Toward a unified view," MIS Q. Manag. Inf. Syst., vol. 27, no. 3, pp. 425-478, 2003, doi: $10.2307 / 30036540$.

[63] G. Viscusi, C. Batini, and M. Mecella, Information systems for eGovernment: A quality-ofservice perspective. 2010.

[64] K. K. K.-K. Wong, "28/05 - Partial Least Squares Structural Equation Modeling (PLS-SEM) Techniques Using SmartPLS," Mark. Bull., vol. 24, no. 1, pp. 1-32, 2013.

[65] Y. Zeng, Y. Wang, Z. Huang, D. Damljanovic, N. Zhong, and C. Wang, "User interests: Definition, vocabulary, and utilization in unifying search and reasoning," in Lecture Notes in Computer Science (including subseries Lecture Notes in Artificial Intelligence and Lecture Notes in Bioinformatics), 2010, vol. 6335 LNCS, pp. 98-107, doi: 10.1007/978-3-642-15470611 . 